\title{
INTERESTING REMINISCENCES
}

\author{
By Colonel A. J. Doran
}

For many years Major A. J. Doran was one of the prominent men of the Territory of Arizona. He first came into Arizona in 1862, being with General Carleton, who commanded what was known as the California Column, a military expedition sent to Arizona and New Mexico to clear the country of a Southern Confederacy force, which had taken possession of Southern New Mexico and the territory now included in Arizona, under General Baylor, who had established headquarters at La Mesilla, where he issued a proclamation declaring himself Governor of Arizona.

After his service in the California Column, Doran returned to California and engaged in mining in that state and Utah for a time. He was a millwright and bridge builder and was engaged in bridge building on the Santa Fe Railroad during its construction; was present when the last spike was driven when the two roads were connected, at Promongory. For a time he was in the employ of the Central Pacific Railroad Company, and he built the first railroad turn-table ever used in the United States, at the foot of Second Street, San Francisco. He then went to the Death Valley country and helped to build the Panamint Mill for Stewart and Jones.

In the fall of 1876 he left Los Angeles for Arizona, and resided here up to the time of his death, which occurred in the Arizona Pioneers' Home, at Prescott, he being superintendent of that institution.

Soon after arriving in Arizona he built the mill at Pinal for the Silver King Mining Company. Afterwards he was superintendent of the Silver King Company for several years.

Major Doran left the Silver King Mine to reside in Florence, where he served Pinal County in many official positions. In 1880 he was elected as a member of the Eleventh Territorial Legislature, the session being held at Prescott. At the next election, that of 1882, he was elected sheriff. After that he served two terms as chairman of the board of supervisors. $\mathrm{He}$ was elected a member of the Fourteenth Territorial Legislature in Prescott. He was also a member of the Sixteenth Legislature, which convened in the city hall in Phoenix. He was also a member of the council in the Seventeenth and Eighteenth Territorial Legislatures and was president of the council in the 
eighteenth session. He served two terms as member of the territorial board of equalization, being first appointed by Governor Lewis Wolfley in 1889. For seven years he was Lieutenant-Colonel of the First Regiment of the Arizona National Guard.

Major Doran was elected to the council of the Twentyfourth Territorial Legislature from Yavapai County, and was chosen president of that body.

Major Doran resided for many years in Pinal County. He built the old and, later, the new court-house and an important school-house. The lumber used in the old court-house at Florence in 1878 was hauled from Prescott at the cost of $\$ 150.00$ per thousand for rough lumber. The new court-house was built in 1889 .

During the time Major Doran served Pinal County as sheriff, the Silver King Mine was in full operation, reducing the ores into silver bars and concentrates. The bars weighed from 100 to 125 pounds and were shipped by express to Casa Grande Station, on the Southern Pacific Railroad, and thence to San Francisco. The Stage was robbed twice while Doran was sheriff, and the bullion taken. The first time there was only one bar on the stage. The stage was held up a short distance from Pinal, where the mill was located. The bar was so heavy the robbers could not handle it, so they secreted it a short distance from the scene of the robbery. Immediate pursuit was given and a search made for the bar of bullion and it was found.

Some months later, according to Major Doran, the stage was held up again, almost at the same place, and three bars of bullion were taken. After the robbery the stage driver returned to Pinal and gave the alarm. The bullion was recovered and two of the robbers were captured. They were convicted and sent to prison for a term of years. One of these robbers Major Doran pursued for about 100 miles into the Tonto Basin Country, before capturing him. He, together with his pal, served their prison terms.

\section{The Silver King Mine}

Major Doran gave the following description of the Silver King Mine:

"The Silver King was a marvelous mine. Its ore shute was 150 feet in length and 75 feet in width, in porphyry formation. It produced about sixteen million of dollars and paid eight millions in dividends to its owners. The first ores were selected and hauled from the mine to Yuma, a distance of 350 miles, from where it was shipped by steamer to San Francisco. The wagon 
freight to Yuma was fifteen cents per pound and the steamer freight was $\$ 25.00$ per ton. This made a total of $\$ 350$. per ton. The ore ran in value from two to four thousand dollars per ton, much of it being almost pure silver. The mine was discovered in the latter part of the year 1873. The road from Silver King to Picket Post, just over the crest of the mountain, was built by General Stoneman, then in command of the military department of Arizona, and was known as "Stoneman's Grade." Two soldiers belonging to his command, and stationed at the post, were discharged and they started to go to Florence, on foot. When they got to the foot of the mountain, on the south side, they stopped to rest. One of them picked up a piece of peculiar looking ore, took it with him to Florence and showed it to Charlie Mason, who was then a resident of Florence. Mason had the ore tested and found that it was very rich in silver, being almost solid ehloride of silver, known to miners as "horn silver." The soldiers disappeared, no one knowing where they went.

"After the ore was tested, Charlie Mason, Billy Long and Mr. Reagan organized a party and went on a hunt for this mine, or the location the ore came from. They made an extended search, but could not find anything, at that time. One of their animals, a white mule, strayed away from the camp about the time the party was ready to return to Florence. Billy Long left the camp in search of the lost mule. He saw him standing on a round, reddish looking hill, sunning himself in the morning sun. Long went up the hill and got the mule and discovered that the mule was standing on the croppings of what was afterwards known as the Silver King Mine.

"They made the location in 1873 and Charlie Mason became the first superintendent of the incorporated company. I relieved Mason as superintendent in 1881. The first mill erected on the mine had five stamps, erected by an old millwright well known in Arizona by the name of Comstock. The second mill had twenty stamps. During the time I was superintendent I made the heaviest single shipment from the Silver King; it consisted of 22 bars of silver, valued at $\$ 70,000$, the result of fifteen days' run, besides concentrates to the value of as much or more than the bullion shipped. The concentrates, usually, were worth $\$ 2,000$ per ton.

"The above is a correct history of the Silver King Mine, which was a rich producer for a number of years. The Silver King Company was incorporated in San Francisco, under the laws of the State of California; its capitalization being $\$ 500,000$ 
or $\$ 1,000,000$. Among the incorporators were J. M. Barney, Charlie Mason, Mr. Reagan and William Long. The mine was worked to a depth of one thousand feet. It was closed down in 1886 because of the decline of silver and the decrease in the value of the ore."

\section{Robberies and Murders}

Arizona, up to 1885 , was a wild country and robberies and murders were frequent. Major Doran gave an account of some of them in an interview with State Historian Thomas E. Farish in 1916 :

"In the year 1882, in the month of September, a stage running from Bisbee to Tombstone, and into Tucson, was held up below Tombstone on a trip from Tucson. This was commonly known as the Bisbee Robbery. Bob Paul, who was the Wells-Fargo messenger, and had a shot-gun, exchanged places with the driver, Philpot, who was carrying the gun and Bob Paul was driving the team. The stage was attacked, Philpot was killed and the treasure taken. Around the place of the robbery were leaves from a book, and the officers hunted for months to find that book, without success, this being the only clue to the perpetrators of the robbery.

"On the 10th of August, following, occurred what became known as the Riverside Robbery. The stage ran between Florence and Globe and was held up about one-half mile from Riverside; the treasure-box was robbed and Collins, the messenger, was killed. The treasure-box was opened and the treasure taken out-about $\$ 1,000$ in gold and $\$ 2,000$ in silver. For some time prior to this robbery there was a man in Florence known as "Red Jack," whose true name was Jack Almer. He was watching outgoing stages and gave the tip to his accomplices that on this stage was a considerable amount of treasure. I was sheriff of Pinal County at the time. The two men committing the robbery were a man by the name of Tuttle and one by the name of Hensley. They took the treasure about 10 o'clock at night and rode to Redfield's Ranch, on the San Pedro River, 75 miles from the scene of the robbery and murder. On the way to the ranch the two thousand dollars in silver, being very heavy and inconvenient to carry, was cached in an arroya about thirty miles from the scene of the robbery. These men were seen and recognized as they were traveling on the road to Redfield's Ranch, where they arrived on the following morning. Hensley, after resting during the day, struck off into the Rincon Mountains, where he was later joined by Almar. Tuttle remained on the ranch, which was his home. On the day after their arrival 
at the Redfield Ranch I arrived with a posse, and having gathered conclusive evidence that Hensley and Tuttle had committed the robbery, and having found on the ranch the shot-gun which Tuttle had used in killing Collins, the messenger, and also a mail sack which had been carried off, I arrested both Tuttle and Redfield and carried them to Florence. "The chain of evidence was now complete, and when confronted with it Tuttle made a full confession of everything, showing that Redfield, who was a man of wealth and position, had planned the robbery and had given Tuttle and Hensley a hatchet to be used in opening the treasure-box, telling them how to do it and what disposition to make of the hatchet, which was to throw it away as far as they could. Tuttle also said that Redfield had planned other robberies and was acting as a protection to the criminals, dividing the spoils at his ranch. Under guard, Tuttle was taken to where the silver was cached and it was recovered. I made a thorough search of Redfield's Ranch, which was a small adobe building, with strong vegas and a dirt roof. In the center of the building was a post running up to the roof, apparently to support the vegas. It occurred to me that this post was unnecessary and I removed it. It set upon a board about twelve or fourteen inches wide and two feet long. I removed this board and underneath it, buried in the dirt floor, was a box containing $\$ 14,000$ in money, supposed to be the money taken from the stage at the time of the Bisbee robbery, mentioned above. I also found the book from which the leaves were torn and scattered around the place where the Bisbee robbery occurred. After the incarceration of the prisoners in Florence a vigilance committee, composed of some of the leading citizens of Florence, was organized to take the prisoners out of my possession and hang them. I doubled the guard at the jail when I learned the intention of the committee, and went to some of the leaders and told them that I had ample evidence to convict the men and that my duty as an officer was to protect them, and that they could not secure these men except over my dead body, and that in the fight some of them would be killed, and that one thing was certain-I could rely on the fidelity of my guards and that as far as I was concerned as an officer of the law, I had my duty to perform. The leaders contended that Redfield being a rich man, would have a trial in some other county and would escape just punishment. I gave them assurance that the men should not be taken from my possession. They replied that with my assurance to that effect they would not attempt to force the jail, but would let the law take its course. About ten days later Major Evans, the deputy 
United States marshal, and known as a determined, fearless man, appeared on the scene with a posse of nine men-noted gun-men - with an order from Judge Pinney, the chief justice of the territory, to deliver Redfield. I was ordered to deliver the men into the custody of the marshal. This request I refused to obey. Evans threatened to take them by force and then I summoned the citizens of the town to guard the jail and to assist me in holding the prisoners. The citizens came in and the bodies of Redfield and Tuttle were found suspended in the jail from the floor beams above. I then told the marshal that I had reconsidered my action and that he could have the man, Redfield. I conducted Marshal Evans to the jail, opened the door and found both men lifeless, as above stated. Evans then said he did not want Redfield. I then requested Evans to do me a favor by making a return on the court order saying that I had offered to deliver the body of Redfield, which he did. "Now," said I, "go to the judge and tell him what has occurred; tell him that I positively refused to obey his order and everything connected with it, as far as you know. Some time after I received a citation from Judge Pinney to appear in Phoenix to show cause why I should not be punished for contempt of court. I went and had an interview with the judge. I showed him Tuttle's confession; showed him the evidence which I had obtained in reference to the robbery; showing conclusively that Redfield had planned the robbery; had received the money, and that Tuttle had done the shooting. The judge studied a few moments and said: "Mr. Sheriff, go home and attend to your duties; when I want you for contempt of court I will send for you." As above stated, Almer joined Hensley in the Rincon Mountains, one of the roughest ranges in Arizona. I went to the Rincons with a posse, being joined by Sheriff Bob Paul, of Pima County, with another posse. We chased the criminals for several days through the mountains and at times exchanged shots with them. They were finally starved out and made a break to cross the Sulphur Springs Valley to Willcox. On their way across the valley they came upon a freighter's camp, from whom they demanded food. The freighter's name was Moore, who knew of the robbery and that these men were wanted. He told them to come back in a few moments and he would put a lot of grub in the tail-end of his rear wagon and they could go and take it, so he would not see them and, therefore, not be made liable for harboring criminals. Moore put the food in the tail-end of his wagon, as he said, and hid himself and drivers in an abandoned adobe house near the road. When the robbers came for the 
food Moore and his party opened fire upon them. They ran into an arroyo, followed by Moore and his drivers, when both were killed."

Major Doran tells of a very interesting and exciting experience with a stage robber, after he had retired from the office of sheriff.

The story follows:

"Having occasion to visit Florence on business, connected with the court, and having transacted the business, I boarded the stage running between Florence and Casa Grande, a distance of twenty-six miles. Midway on the stage journey, with myself as the only passenger on the stage, the stage was held up by a lone horseman. I was ordered to give up my money and whatever I had, which I did at the point of a pistol. After robbing me the man turned and robbed the driver of a like amount of money, getting exactly two dollars from each of us. He then turned to the driver, with pistol pointed at him, ordered him to throw out the mail sack, which was unhesitatingly done, the mail sack alighting on the ground close to the front wheel of the stage. He then ordered me to open the mail sack, which I did after some dilatory objections. I told him that I could not open the sack, as I had no key and did not want to open the government mail, as it might cause serious trouble for me. The man said: "You have a knife, haven't you?" I said: "Yes," and he then said: "Take your knife and open it." I then cut the sack open with my knife, all the time getting a little closer to him. The man was on one side of the sack with his pistol drawn on me, with his finger on the trigger, and I made a calculation that if the pistol was discharged the bullet would strike me in the breast. I got the mail sack and doubled up my knife to put it in my pocket, when the robber took it away from me. "Now," he said, "empty the sack," which I did and the contents fell in a heap on the ground between us. He swore at me and said: "I don't see any money in that." "No," I said, "I don't see any money either and I don't believe there is any money in it." All this time I was getting a little closer to the robber. At last with my foot $I$ spread the mail out on the ground, concluding that the robber would look down to see what was uncovered. The robber did as I supposed he would, when I made a grab for his gun and a fight commenced for its possession between the robber and myself. I was quick in throwing the gun to one side, so that if it went off it would not hurt me, the horses or the driver. I called to the driver, saying "come quick for we have got this fellow," but the driver did not come, but left me to 
fight alone with the robber. Finally the robber got possession of his pistol and ran away about two rods and threatened to kill me, which he could have done had he not changed his mind and put his pistol in the holster, jumped on his horse and rode away across the plains. I then gathered up the mail, put it in the sack and took it under my supervision and delivered it to the postmaster at Casa Grande. I gave the alarm and the officers, a deputy-United States marshal and a man who later developed into a noted outlaw, went after the robber and picked him up in a couple of days. He was brought back to Florence, where court was in session, and in seven days from the time of the attempted robbery he was on his way to Alcatraz Island, in San Francisco Harbor, with a life sentence. He served about ten years, having in the meantime been transferred to San Quentin Prison. I concluded he had been punished enough, and being in Washington, I went to the president and asked him to take such action in the case as he deemed best. The president sent his application for pardon to the judge who tried him, and to the United States attorney who prosecuted him, through the Department of Justice, saying if they would recommend it, that he would act as I had requested, which he did, commuting the sentence to twelve years of actual service. I met the robber in Los Angeles, after his release from prison, and had dinner with him, when we talked over our fight on the desert. The robber afterwards became a lieutenant-colonel in the federal army in Mexico."

Note.-At the time Major Doran was elected sheriff of Pinal County, that county was in bad shape; the whiskey men, gamblers and rough element were running the county, and under the administration of a former sheriff conditions had drifted from bad to worse, until, for self-protection, the decent element of the county organized to bring about a change, regardless of politics. Doran, who, as manager of the Silver King Mine, had displayed great courage and determination in ridding the camp of those who, as miners, were stealing the ore, was urged to become a candidate for sheriff. He consented, and although he was a republican and the county strongly democratic, he was elected as a reform officer.

Major Doran was commissioner from Pinal County to the New Orleans Cotton Exposition in 1886, and was later named as president of the Arizona Fair Commission at the St. Louis Exposition in 1894, being on the ground during the entire exposition. 
In the 24th Territorial Legislature Major Doran introduced a bill for the creation of a pioneer's home for the Territory of Arizona, where pioneers in their declining years could be properly cared for, at the expense of the territory. This bill was passed by the legislature, unanimously, but did not receive the approval of the governor. In the 25th Territorial Legislature this pioneer home bill was re-introduced by George Morris, of Yavapai County, and was passed. Major Doran built the Pioneers' Home at Prescott and was its first superintendent. He died at the home.

Note.-Mr. Reagan, who was one of the owners of the Silver King Mine, as above stated, in 1884, after the discovery of the mine, before it became an active producer, was a hotel keeper in Florence and attached to the hotel was a bar. Reagan had an altercation with a man, a discharged soldier, who became very abusive and threatening, when Reagan drew a knife and stabbed him to death. Reagan then made the coffin for his victim, and being a Campbellite preacher, officiated at the funeral; delivering the sermon; leading in prayer and the general services. 